\title{
Effect of Forest Management Operations on Aggregate-Associated SOC Dynamics Using a ${ }^{137}$ Cs Tracing Method
}

\author{
Geng Guo ${ }^{1}$, Xiao Li ${ }^{1,2}{ }^{,} \mathrm{Xi} \mathrm{Zhu}^{1}{ }^{1}$, Yanyin $\mathrm{Xu}{ }^{1}$, Qiao Dai ${ }^{1}$, Guangruo Zeng ${ }^{3}$ and Jie Lin ${ }^{1, *}$ \\ 1 Co-Innovation Center for Sustainable Forestry in Southern China of Jiangsu Province, Key Laboratory of Soil \\ and Water Conservation and Ecological Restoration of Jiangsu Province, Nanjing Forestry University, \\ Nanjing 210037, China; gengguoacademy@njfu.edu.cn (G.G.); Lxiao@webmail.hzau.edu.cn (X.L.); \\ jiaxichuan@njfu.edu.cn (X.Z.); 1809908680@njfu.edu.cn (Y.X.); daiqiao@njfu.edu.cn (Q.D.) \\ 2 College of Resources and Environment, Huazhong Agricultural University, Wuhan 430070, China \\ 3 Academy of Forestry of Ji'an City, Ji'an 343000, China; jinchenying@njfu.edu.cn \\ * Correspondence: jielin@njfu.edu.cn
}

Citation: Guo, G.; Li, X.; Zhu, X.; Xu, Y.; Dai, Q.; Zeng, G.; Lin, J. Effect of Forest Management Operations on Aggregate-Associated SOC Dynamics Using a ${ }^{137} \mathrm{Cs}$ Tracing Method. Forests 2021, 12, 859. https://doi.org/ $10.3390 /$ f12070859

Academic Editor:

Marcin Pietrzykowski

Received: 21 April 2021

Accepted: 25 June 2021

Published: 29 June 2021

Publisher's Note: MDPI stays neutral with regard to jurisdictional claims in published maps and institutional affiliations.

Copyright: (c) 2021 by the authors. Licensee MDPI, Basel, Switzerland. This article is an open access article distributed under the terms and conditions of the Creative Commons Attribution (CC BY) license (https:// creativecommons.org/licenses/by/ $4.0 /)$.

\begin{abstract}
Although forest conversions have long been a focus in carbon (C) research, the relationship between soil erosion and the dynamic change of soil organic carbon (SOC) has not been wellquantified. The objective of this study was to investigate the effects of converting CBF (coniferous and broad-leaved mixed forests) to economic forests, including CF (chestnut forest), HF (hawthorn forest), and AF (apple forest), on the soil structure and nutrient loss in the Huaibei Rocky Mountain Areas, China. A ${ }^{137} \mathrm{Cs}$ tracer method was used to provide soil erosion data in order to quantify the loss of aggregate-associated SOC. The results showed that forest management operations caused macro-aggregates to decrease by $1.69 \%$ in $\mathrm{CF}, 4.52 \%$ in $\mathrm{AF}$, and $3.87 \%$ in HF. Therefore, the stability of aggregates was reduced. The SOC contents in each aggregate size decreased significantly after forest conversion, with the largest decreases occurring in AF. We quantified the loss of 0.15, 0.38, and $0.31 \mathrm{Mg} \mathrm{hm}^{-2}$ of aggregate-associated SOC after conversion from CBF to $\mathrm{CF}$, $\mathrm{AF}$, and $\mathrm{HF}$, respectively. These results suggest that forest management operations have a negative impact on soil quality and fertility. CF has better vegetation coverage and less human interference, making it more prominent among the three economic forests species. Therefore, when developing forest management operations, judicious selection of tree varieties and appropriate management practices are extremely critical. In addition, measures should be taken to increase surface cover to reduce soil erosion and achieve sustainable development of economic forests.
\end{abstract}

Keywords: forest management operations; ${ }^{137} \mathrm{Cs}$; soil aggregate; soil erosion

\section{Introduction}

Soil is the largest terrestrial carbon (C) pool in the world, and it contains at least three times as much $\mathrm{C}$ as the atmosphere [1]. It was reported that the terrestrial $\mathrm{C}$ stock releases about $4 \%$ of its pool into the atmosphere each year [2]. Therefore, the potential $\mathrm{CO}_{2}$ emissions from terrestrial ecosystems are of great importance to the continentaland regional-scale $\mathrm{C}$ balance [3]. The distribution of aggregate and aggregate-associated soil organic carbon (SOC) determines the capacity of the soil to store and retain C [4]. Aggregates are the structural units of the soil, and SOC is the critical binding material of aggregates. The differences in size distribution and the stability of aggregates control the changes of microbial activities and nutrient cycling, which in turn affects the soil biogeochemical and biophysical processes [5,6]. Aggregate formation is considered as one of the most important mechanisms of SOC sequestration [7]. Hence, understanding SOC dynamics in aggregates is crucial for developing effective management strategies to mitigate global warming and improve soil quality, which can contribute to the sustainable development of the environment. 
Forest soils have great potential for $\mathrm{C}$ fixation [8,9]. The global forest ecosystem C storage is $861 \pm 66 \mathrm{Pg}$, and the soil C pool (to $1 \mathrm{~m}$ depth) accounts for $44 \%$ of this storage [10]. Numerous studies have demonstrated that forest conversion has significant impacts on the stability of aggregates and dynamics of aggregate-associated SOC and other nutrients in soils [11-13]. The forestry management practice, such as tillage scheme, the removal of litter, intermediate cutting, fertilizer treatment, and other measures, destroys macro-aggregate and breaks into small particles, and thus increases the amount of microaggregates, which in turn facilitates the transport of SOC between size classes [14,15]. As a result, the forestland is susceptible to water erosion, and aggravates the loss of carbon enriched in micro-aggregates. The effect of changes in land-use on SOC sequestration is mainly responsible for the changes in the renewal and transformation of micro-aggregates, thus altering the mechanism of SOC. Recent research mainly focused on the effects of agricultural management practices on the stability of aggregates and related SOC at the global scale [16-18]. However, reports on the effects of forest conversion on the distribution of aggregates and associated SOC content at the catchment scale are relatively few. Furthermore, the total soil $\mathrm{C}$ is not very sensitive to the effects of forest management operations in the short term. As many researchers suggested, the content of TC in soils is high and it is subject to a series of factors, not only the land-use change, tillage practice, and other factors. More importantly, TC is also affected by its intrinsic mechanism [18-22]. In contrast, the smaller $C$ fractions such as the aggregate-associated SOC is more effective to the changes in land-use, and the aggregate-associated is a sensitive indicator to characterize the change in soil carbon pools and soil erosion. Therefore, a greater understanding of the effects of the forest management practices, especially forest conversion, on aggregate-associated SOC dynamics during the forest construction process is needed to characterize the SOC contents that result from changes in land-use.

Since the implementation of the "Grain for Green" program in 1999, planted forests in China have developed rapidly to become the world's largest planted forest storage area [23]. Large-scale afforestation improves the stability of soil aggregates and increases the SOC content of aggregates $[8,11,24]$. Afforestation, the conversion of non-forested land into forest, protects the surface soils from wind and water erosion, and enhances the stability of aggregate and aggregate-associated SOC by generating macro-aggregates through mycorrhizal interaction with plant roots and microbes [25]. In addition, forest conversion could sequester $\mathrm{CO}_{2}$ from the atmosphere and store it into plants via vegetation photosynthesis, eventually transforming it into soil organic matter through humification [11]. However, over the past two decades, native forests have increasingly been converted into economic forests to meet the increasing demands for timber, as well as for raw material for pulp, paper, fuel, and other forest products [26-28]. Forest management practices, such as fertilizer treatments, reduced tillage, and mulching, have been used to manage plantations to obtain better soil structure, and increase forest productivity and biomass $\mathrm{C}$ storage in forest ecosystems [29]. Thus, improved understandings of the conversion of forests to economic forests is necessary. However, numerous studies have shown that forest management would decrease SOC storage or stability [11,30,31]. For example, understory vegetation removal results in the reduction of SOC storage or stability due to decreased C input into the soil [32,33]. Simultaneously, soil aggregate size significantly impacts soil bacterial and fungal communities. The breakdown of aggregates exerted an apparent influence on the respiration of soil bacteria (such as Psathyrellaceae, Bacillaceae, and Rhizophlyctidaceae), and soil fungi (such as Nectriaceae) lived in aggregate, which in turn inhibited the binding of clay- and silt-sized particles to form micro-aggregates within macro-aggregates, thereby influencing the stability of SOC $[8,34]$. The effects of forest conversion on soil quality have been extensively studied [17,35-37]. However, the relationships between soil structure stability and dynamic changes of SOC from the perspective of soil erosion have not been fully investigated following the economic forest conversion, especially in Huaibei Rocky Mountain Area, China. Tillage practices, fertilizer treatments, land-use change, and other forestry management measures contribute to the breakdown of original soil structure, and 
the decline of soil quality, resulting in the decrease in the anti-erosion function. Effects of soil erosion on soil profile interception and carbon stocks are often overlooked, although soil erosion is the most widespread event accompanying forest conversion [38]. Worldwide, soil erosion redistributes approximately $75 \mathrm{Pg}$ of soil and 1-5 Pg of SOC annually [39]. Thus, studying the stability of soil aggregates and the dynamic changes of associated SOC in response to soil erosion is essential for sustainable forestry management and yield.

The formation and destruction of soil aggregates are both closely related to soil erosion [19]. Increasing the content of $>0.25 \mathrm{~mm}$ aggregates contributes to a better soil structure and enhances soil erosion resistance [40]. Previous studies have focused on the qualitative description of the effects of soil erosion on the aggregate-associated SOC content $[14,22,40]$. Little research has been carried out to quantify the amount of aggregateassociated SOC loss caused by soil erosion, which is vital for calculating the global C balance. The isotope ${ }^{137} \mathrm{Cs}$ is a unique artificial radionuclide produced by nuclear tests, and it has been widely used in soil erosion research at different spatial scales around the world since the 1990s [41]. This method is simple, highly quantitative, low cost, and reliable. It has proven to be the best method to study soil erosion $[38,42]$. Studies have reported that ${ }^{137} \mathrm{Cs}$ has similar migration patterns as SOC in soil aggregates $[3,14,43]$. Therefore, exploring the relationship between the SOC content in aggregates of different sizes and ${ }^{137} \mathrm{Cs}$ content can further reveal the internal relationship between the two. In summary, soil aggregation is a critical mechanism for the stability of soil organic matter (SOM), especially SOC. Soil aggregation affects many of the key properties of soil, such as physicochemical properties, and microbial activities in that it shapes the habitats available to the microorganisms. Consequently, aggregates are conducive to the SOC sequestration and soil structural stability and improve the soil ability to resist erosion. Although there are studies to investigate the effect of erosion on SOC, there are few studies that have quantified the dynamic changes of aggregate-associated SOC induced by soil erosion, especially by means of Cesium 137. Therefore, even fewer studies have investigated these changes in the context of forest conversion. To quantify this relationship, a ${ }^{137} \mathrm{Cs}$ isotope tracer technology was selected in this study. The aims of this study are (i) to investigate the effects of forest conversion on soil aggregate composition and stability, (ii) to quantify soil erosion and aggregate-associated SOC loss after forest conversion, and (iii) to compare different types of economic forests and management practices to identify reasonable forestry management patterns that can serve as a basis for sustainable development of economic forests, which reduces ecological and environmental problems.

\section{Materials and Methods}

\subsection{Site Description}

Soil samples were collected from the Dawu Mountain, situated in the northwest of Ganyu District of Lianyungang City, Jiangsu Province, China ( $\left.35^{\circ} 0^{\prime} 39.7^{\prime \prime} \mathrm{N}, 118^{\circ} 57^{\prime} 55.2^{\prime \prime} \mathrm{E}\right)$ (Figure 1). The full site description and experimental design are described by Zhu et al. [38]. Briefly, this region has a humid warm temperate maritime monsoon climate with a mean annual temperature (MAT) of $13.9^{\circ} \mathrm{C}$. The mean annual precipitation (MAP) is $976.6 \mathrm{~mm}$, concentrated from May to September. The annual average sunshine period is $2534 \mathrm{~h}$ and the annual average period free of frost is 216 days. Topographically, the slopes in this area generally range from $11^{\circ}$ to $15^{\circ}$ and the altitude of the region ranges from 190 to $364.4 \mathrm{~m}$ above sea level (ASL).

The soils at the experimental site were classified as Alfisols using the FAO soil classification system [44]. Bulk density (BD) ranged from 1.34 to $1.27 \mathrm{~g} \mathrm{~cm}^{-3}$. Soil $\mathrm{pH}$ was all acidic at 4.47-5.18, and the specific surface area (SSA) in soils ranged from 1.57 to $3.50 \mathrm{~m}^{2} \mathrm{~g}^{-1}$, which shows no remarkable difference between forest land-use types. Detailed information about the soil physical and chemical conditions is listed in Tables 1 and 2. The soils in this region have a silty loam texture and the soil layers are thin, which are very vulnerable to water and tillage erosion [38]. 
The study area is a temperate deciduous broad-leaved forest region, with forest plantations dominating, and a minority of natural deciduous broad-leaved forests and evergreen coniferous forests were supplemented prior to the 2000s, which included secondary vegetation such as Masson massoniana Lamb., Celtis sinensis Pers., and Quercus L., and other economic trees such as hawthorn and chestnuts. By the early 21st century, some of the forest plantations were in a state of natural regeneration, and others were converted into economic forests by the locals to obtain economic profits. According to the field survey, coniferous and broad-leaved mixed forests (CBF) are the dominant stand types of forest plantations, and the dominant tree species are Pinus massoniana, Platycladus orientalis, and Metasequoia glyptostroboides. There are herbaceous plants and humus layers in the understory trees or shrubs. CBF has a complex structure with shrub, grass, and litter in the understory, and has a prosperous root system. The hawthorn forest (HF), the chestnut forest $(\mathrm{CF})$, and the apple forest $(\mathrm{AF})$ are all economic forests transformed from $\mathrm{CBF}$, among which the CF was covered with litter on the surface, the AF was bare on the surface with obvious traces of artificial tilling, and understory vegetation of HF was removed each year [38]. In addition, through the inquiry with the local farmers, significant amounts of fertilizers $\left(\mathrm{P}_{2} \mathrm{O}_{5}: 109 \mathrm{~kg} \mathrm{ha}^{-1}\right.$ year $^{-1}$ as ordinary superphosphate, $\mathrm{N}$ : $214 \mathrm{~kg} \mathrm{ha}^{-1}$ year $^{-1}$ as urea and ammonium bicarbonate) were generally applied into the economic forests in May of each year.

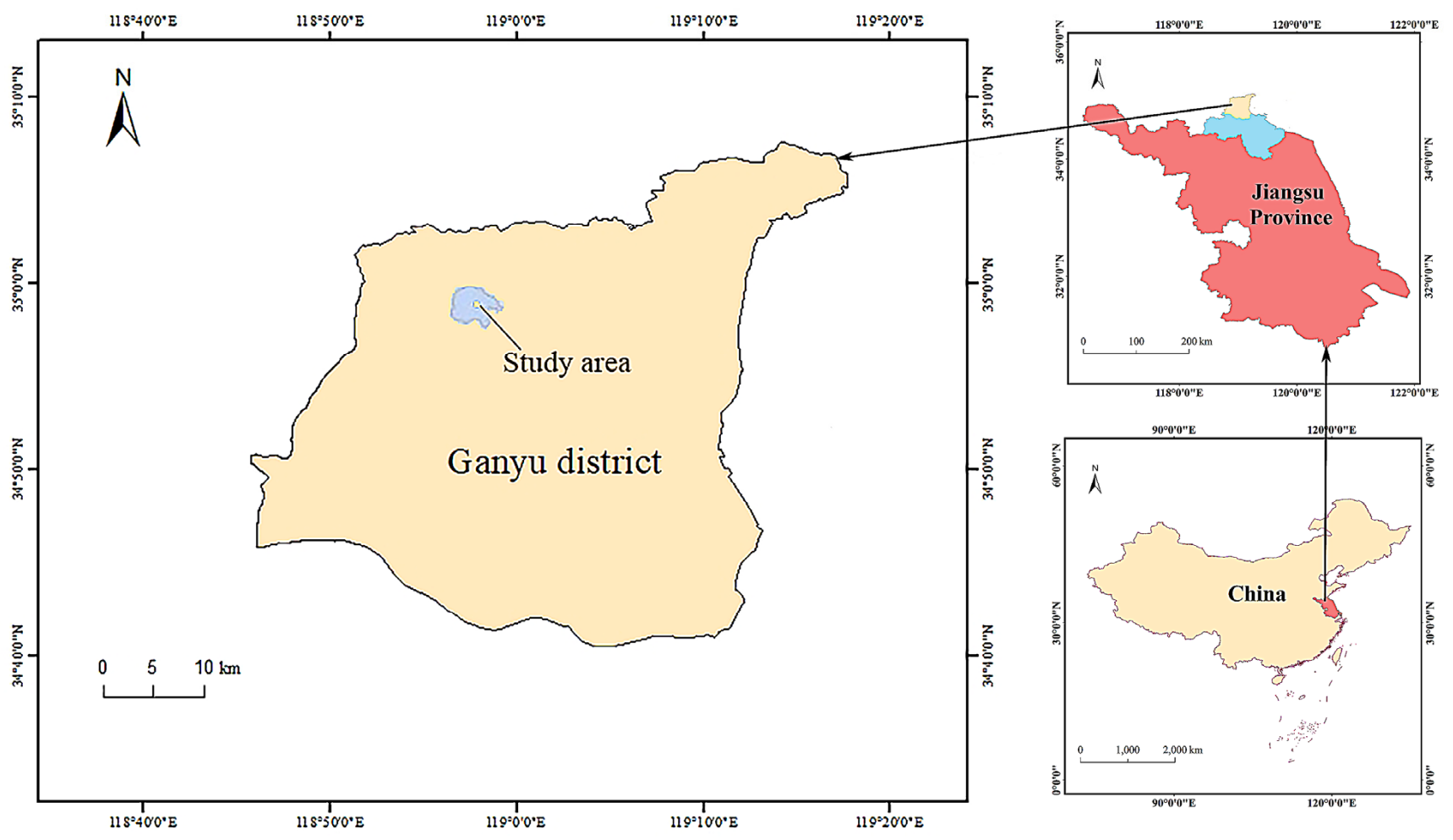

Figure 1. Location of the study site. 
Table 1. Basic information of the study area.

\begin{tabular}{|c|c|c|c|c|c|c|c|c|c|c|}
\hline Forest & Human & Age [38] & LAI [38] & $\begin{array}{c}\text { Litter } \\
\text { Thickness [38] }\end{array}$ & Slope [38] & Aspect [38] & $\begin{array}{c}{ }^{137} \text { Cs Content } \\
{[38]}\end{array}$ & $\begin{array}{c}\text { Percentage }^{137} \mathrm{Cs} \\
\text { Loss }[38]\end{array}$ & $\begin{array}{l}\text { Soil Erosion } \\
\text { Modulus }\end{array}$ & $\begin{array}{c}\text { Soil Loss } \\
\text { Thickness }\end{array}$ \\
\hline Types & interference & (year) & & $(\mathrm{mm})$ & $\left(^{\circ}\right)$ & & $\left(\mathrm{Bq} \mathrm{m}^{-2}\right)$ & $(\%)$ & $\left(\mathrm{t} \mathrm{km}^{-2} \mathrm{a}^{-1}\right)$ & $(\mathrm{mm})$ \\
\hline $\mathrm{CBF}$ & None & 25 & 3.2 & 1.3 & 13 & SE & 546.92 & 68.4 & 1113.73 & 0.79 \\
\hline $\mathrm{CF}$ & Weak & 13 & 2.5 & 1.1 & 11 & SE & 495.89 & 71.4 & 1275.35 & 0.87 \\
\hline $\mathrm{AF}$ & Strong & 10 & 2.2 & 0 & 13 & SE & 60.6 & 96.5 & 3328.2 & 2.31 \\
\hline $\mathrm{HF}$ & Strong & 11 & 2.1 & 0 & 15 & SE & 123.89 & 92.9 & 2606.7 & 1.84 \\
\hline
\end{tabular}

Note: All the data were calculated on the basis of three replicates and represented as average \pm SE (standard error). 
Table 2. Soil physicochemical properties of different forest types.

\begin{tabular}{ccccc}
\hline Parameters & CBF & CF & AF & HF \\
\hline$B D\left(\mathrm{~g} / \mathrm{cm}^{3}\right)[38]$ & $1.44 \pm 0.12 \mathrm{~A}$ & $1.43 \pm 0.05 \mathrm{~A}$ & $1.47 \pm 0.18 \mathrm{~A}$ & $1.42 \pm 0.12 \mathrm{~A}$ \\
\hline $\mathrm{pH}[38]$ & $5.67 \pm 0.27 \mathrm{AB}$ & $5.95 \pm 0.34 \mathrm{~A}$ & $5.48 \pm 0.26 \mathrm{~B}$ & $5.67 \pm 0.27 \mathrm{~A}$ \\
\hline Sand $(\%)[38]$ & $36.59 \pm 7.53 \mathrm{AB}$ & $31.57 \pm 7.83 \mathrm{BC}$ & $41.07 \pm 8.65 \mathrm{~A}$ & $30.84 \pm 5.05 \mathrm{C}$ \\
\hline Silt $(\%)[38]$ & $60.21 \pm 6.96 \mathrm{AB}$ & $64.66 \pm 6.66 \mathrm{~A}$ & $56.63 \pm 4.36 \mathrm{~B}$ & $65.00 \pm 5.63 \mathrm{~A}$ \\
\hline $\mathrm{Clay}(\%)[38]$ & $3.20 \pm 0.41 \mathrm{AB}$ & $3.77 \pm 0.18 \mathrm{AB}$ & $2.29 \pm 0.23 \mathrm{~B}$ & $4.16 \pm 0.36 \mathrm{~A}$ \\
\hline $\mathrm{SSA}\left(\mathrm{m}^{2} \mathrm{~g}^{-1}\right)$ & $2.14 \pm 0.17 \mathrm{~A}$ & $2.26 \pm 0.23 \mathrm{~A}$ & $3.07 \pm 0.43 \mathrm{~A}$ & $2.57 \pm 0.82 \mathrm{~A}$ \\
\hline $\mathrm{TN}\left(\mathrm{g} \mathrm{kg}^{-1}\right)$ & $2.57 \pm 0.32 \mathrm{~A}$ & $1.35 \pm 0.11 \mathrm{~B}$ & $1.21 \pm 0.03 \mathrm{~B}$ & $1.52 \pm 0.10 \mathrm{~B}$ \\
\hline $\mathrm{C} / \mathrm{N}^{\mathrm{C}} / \mathrm{H}^{-1}$ & $9.10 \pm 0.26 \mathrm{~A}$ & $7.03 \pm 0.67 \mathrm{BC}$ & $6.66 \pm 0.16 \mathrm{C}$ & $7.73 \pm 0.26 \mathrm{BC}$ \\
\hline $\mathrm{SOC}\left(\mathrm{g} \mathrm{kg}^{-1}\right)$ & $30.86 \pm 4.87 \mathrm{~A}$ & $18.87 \pm 1.50 \mathrm{~B}$ & $11.55 \pm 2.18 \mathrm{~B}$ & $13.83 \pm 1.78 \mathrm{~B}$ \\
\hline $\mathrm{DOC}\left(\mathrm{g} \mathrm{kg}^{-1}\right)$ & $0.27 \pm 0.02 \mathrm{~A}$ & $0.26 \pm 0.02 \mathrm{~A}$ & $0.27 \pm 0.06 \mathrm{~A}$ & $0.23 \pm 0.06 \mathrm{~A}$ \\
\hline
\end{tabular}

Note: Values are means $\pm \mathrm{SE}(n=3)$. The different capital letters indicate significant differences in the topsoil among different forest types $(p<0.05)$. SSA: specific surface area.

\subsection{Experimental Design and Soil Sampling}

After evaluation of the site and consultation with the owners of the forest, a series of sites were selected in the Dawu Mountain watershed. The CBF serves as the control. The comparison between CBF and the other three economic forests (CF, HF, and $\mathrm{AF}$ ) allows us to evaluate the effect of forest management operations. Different soil erosion sequences allow us to assess the impact of intensive management on the soil. Each of these stand types were replicated three times, and the distance between each plot was over $50 \mathrm{~m}$. The forests selected exhibited similar site conditions, such as soil type, elevation, slope gradient, and aspect. Site data for the four forest types are included in Table 1, and for more detailed information, refer to Zhu et al. [38]. Within each stand, a $400 \mathrm{~m}^{2}(20 \times 20 \mathrm{~m})$ plot was established in July 2016. A total of 12 plots were established in this study. An "S" strip sampling strategy was chosen for each sub-quadrate plot to ensure the representativeness of soil samples in each plot. Soil samples were collected from 0 to $30 \mathrm{~cm}$ depth from three randomly selected points in each plot and were thoroughly mixed to form a composite sample for determination of basic physical and chemical properties. Samples were also collected from each plot to measure bulk density using a corer, with a $200 \mathrm{~cm}^{3}$ volume. For aggregate analyses, samples were collected with a hard aluminum box following the previous steps and transported to the laboratory for further analyses. In addition, based on the results of our research group, two sampling points on the top of Dawu Mountain were determined, and their average value of ${ }^{137} \mathrm{Cs}\left(1732.48 \mathrm{~Bq} / \mathrm{m}^{2}\right)$ was chosen as the background value. Soil nuclide ${ }^{137} \mathrm{C}$ s sampling and calculation were conducted according to the study of Zhu et al. [38].

\subsection{Soil Analysis}

Soil samples were air-dried, crushed, and then passed through a $2 \mathrm{~mm}$ mesh sieve to filter out coarse materials after removing all the visible plant materials for the measurement of subsequent analyses. Soil bulk density (BD) was calculated as the ratio of oven-dried undisturbed core weight to container volume on the basis of a core method (at $105{ }^{\circ} \mathrm{C}$ for $24 \mathrm{~h}$ ). The soil $\mathrm{pH}$ was determined by a soil-water ratio of 1:2.5 using a $\mathrm{HI}$ $3221 \mathrm{pH}$ meter (Hanna Instruments Inc., Woonsocket, RI, USA). The particle size distribution of soil samples was determined by a Mastersizer 2000 laser diffraction particle size distribution analyzer (Malvern Instruments Ltd., Malvern, UK). The specific surface area (SSA) value was determined by physical absorption of nitrogen gas using an automatic apparatus-ASAP 2020 HD 88 analyzer (Micromeritics Instrument Corp., Norcross, GA, USA), operated at $77 \mathrm{~K}$. More details on the experimental instruments and procedures were 
reported by Zhao et al. [45]. Afterwards, the samples were then passed through a $0.15 \mathrm{~mm}$ mesh, and the total nitrogen $(\mathrm{TN}), \mathrm{C} / \mathrm{N}$, and $\mathrm{C} / \mathrm{H}$ ratios were measured by way of the dry combustion method via a Vario Max elemental analyzer (Elementar, Langenselbold, Germany). Soil organic carbon (SOC) content was tested with the vitriol acid-potassium dichromate wet oxidation method [46]. Dissolved organic carbon (DOC) was determined using the Shimadzu TOC-VCPH analyzer (Shimadzu Corp., Kyoto, Japan). The detailed procedures follow Jones' procedure [47]. Three replicates were completed for each sample.

\subsection{Soil Aggregate Fractionation}

Soil aggregation was characterized by the water aggregate size distribution, and aggregates were separated following the modified method described by ISSAS [48]. Four water-stable aggregates were manually fractionated by sieving $100 \mathrm{~g}$ soil through a set of sieves with apertures of $1.0,0.5$, and $0.25 \mathrm{~mm}$. The top sieve was equipped with a cover prior to submerging the sieves in water. The three size fractions at the macro-aggregate scale $(>1.0,0.5-1.0$, and $0.25-0.5 \mathrm{~mm})$ and one fraction aggregate at $<0.25 \mathrm{~mm}$ (micro-aggregate) were obtained. Briefly, all the sieves were immersed in deionized water and were moved up and down approximately $6 \mathrm{~cm}$ for $5 \mathrm{~min}$, with 25 repetitions per minute. After $30 \mathrm{~min}$ of oscillation, the aggregate fractions remaining on each sieve were transformed from the sieves for four size classes with the deionized water into an $\mathrm{Al}$ container and dried at $105{ }^{\circ} \mathrm{C}$ for $24 \mathrm{~h}$ and weighted to calculate the mean weight diameter (MWD) and geometric mean diameter $(G M D)$. The equations of $M W D$ and $G M D$ refer to [49,50].

\subsection{Calculations}

Using the mass of the soil particle distribution and the above calculation results, the fractal dimensions $(F D)$ and the soil erodibility factor $(K)$ to characterize soil erosion resistance [51] were calculated by the following equations:

$$
\begin{gathered}
\lg \left[\frac{M(r<\mathrm{R} i)}{M \mathrm{~T}}\right]=(3-F D)\left(\frac{R i}{R_{\max }}\right) \\
K=7.954 \times\left\{0.0017+0.0494 \times \exp \left[-0.5 \times\left(\frac{\log G M D+1.675}{0.6896}\right)^{2}\right]\right\},
\end{gathered}
$$

where $R_{i}(\mathrm{~mm})$ is the mean aggregate diameter of all size classes, $R_{\text {max }}(\mathrm{mm})$ is the mean diameter of the largest aggregates, $M\left(r<R_{i}\right)(\mathrm{g})$ is the cumulative soil mass of particle sizes smaller than $R_{i}, M_{T}(\mathrm{~g})$ is the total mass of all size fractions, $F D$ is the soil fractal dimension, and $K$ is the soil erodibility factor.

\subsection{SOC Storage Estimation}

Area-based estimates of elements $\left(\mathrm{Mg} \mathrm{hm}^{-2}\right)$ have been commonly accepted as the most appropriate means to describe standing stocks of $\mathrm{C}$ in soils. Element masses in genetic horizons were calculated from the thicknesses and bulk densities of the horizons [52]:

$$
\begin{aligned}
& M_{\text {soil }}=B D \times T \times 0.01 \times 10000 \\
& M_{\text {element }}=M_{\text {soil }} \times \text { conc } \times 0.001
\end{aligned}
$$

where $M_{\text {element }}\left(\mathrm{Mg} \mathrm{hm}^{-2}\right)$ is the element mass per unit area, conc $\left(\mathrm{g} \mathrm{kg}^{-1}\right)$ is the soil aggregate organic $C$ content, $M_{\text {soil }}\left(\mathrm{Mg} \mathrm{hm}^{-2}\right)$ is the soil mass per unit area, $1 \mathrm{Mg}=10^{3} \mathrm{~kg}$, $B D\left(\mathrm{~g} \mathrm{~cm}^{-3}\right)$ is field bulk density, $T(\mathrm{~m})$ is the soil layer thickness or soil loss thickness, and $0.001,0.01$, and 10,000 are unit conversion factors.

\subsection{Statistical Analysis}

The data presented in this paper are the average of three replications. A one-way analysis of variance (ANOVA) was conducted to test the effects of forest conversion and subsequent intensive management on the physical and chemical properties, aggregate 
distribution and stability, and related organic C dynamics. Before performing the ANOVA, the normality and homogeneity of variance were tested, and data were log-transformed if homogeneity of the variance was not met. When the ANOVA indicated a significant treatment effect, the least significant difference (LSD) test was used to separate the means. An alpha level of 0.05 for significance was used in all statistical analyses, unless otherwise mentioned. A stepwise correlation analysis was applied to investigate the correlation between ${ }^{137} \mathrm{Cs}$ and aggregate-associated SOC content. All of the statistical analyses in this study were performed using the SPSS software (SPSS 25.0 for windows, SPSS Inc., Chicago, IL, USA). The figures were created with the Origin Pro 2016 software (OriginLab Corporation, Northampton, MA, USA).

\section{Results}

\subsection{Soil Physicochemical Properties after Forest Conversion}

Total SOC concentrations in CF, AF, and HF decreased by $38.9 \%, 62.6 \%$, and $55.2 \%$ respectively, as compared to levels in CBF (Table 2). The soil total $\mathrm{N}$ concentration ranged from 1.21 to $1.52 \mathrm{~g} / \mathrm{kg}$ among economic forests, and these levels were significantly lower than those in CBF (Table 2). A similar trend was observed for the $\mathrm{C} / \mathrm{N}$ and $\mathrm{C} / \mathrm{H}$ ratios (Table 2). The lowest value for $\mathrm{pH}$ and silt + clay contents was observed in AF. The specific surface area (SSA) exhibited an increasing trend after forest conversion, especially in the conversion from $\mathrm{CBF}$ to $\mathrm{AF}$. There were no significant differences in $B D$ and $\mathrm{DOC}$ regardless of forest conversion and subsequent intensive management.

\subsection{Soil Aggregate Fractions and Stability}

The economic forest management clearly increased the proportion of micro-aggregates $(<0.25 \mathrm{~mm})$. After forest conversion, there was a decrease in the proportion of macroaggregates $(>0.25 \mathrm{~mm})$ and an increase in micro-aggregates $(<0.25 \mathrm{~mm})$. Macro-aggregate content for $\mathrm{CBF}(72.11 \%)$ was significantly higher than $\mathrm{CF}(70.42 \%), \mathrm{AF}(67.59 \%)$, and $\mathrm{HF}$ $(68.14 \%)$. The proportion of micro-aggregates for $\mathrm{AF}$ was $32.41 \%$, approximately 1.16 times higher than CBF. Results show that $3.39 \%$ of macro-aggregates were broken down into micro-aggregates due to the conversion from CBF to economic forests (Table 3).

Table 3. Soil aggregate distribution and stability for different forest types.

\begin{tabular}{ccccc}
\hline Parameters & CBF & CF & AF & HF \\
\hline$>1 \mathrm{~mm}(\%)$ & $21.56 \pm 2.08 \mathrm{~A}$ & $19.6 \pm 1.21 \mathrm{~B}$ & $16.35 \pm 1.81 \mathrm{C}$ & $14.81 \pm 1.56 \mathrm{C}$ \\
$1-0.5 \mathrm{~mm}(\%)$ & $26.64 \pm 2.65 \mathrm{~A}$ & $24.31 \pm 1.64 \mathrm{~A}$ & $23.86 \pm 1.17 \mathrm{~A}$ & $25.81 \pm 1.44 \mathrm{~A}$ \\
$0.5-0.25 \mathrm{~mm}(\%)$ & $23.91 \pm 2.02 \mathrm{~B}$ & $26.52 \pm 1.45 \mathrm{~A}$ & $27.38 \pm 0.90 \mathrm{~A}$ & $27.52 \pm 1.47 \mathrm{~A}$ \\
$<0.25 \mathrm{~mm}(\%)$ & $27.89 \pm 2.73 \mathrm{C}$ & $29.58 \pm 1.79 \mathrm{~B}$ & $32.41 \pm 2.13 \mathrm{~A}$ & $31.86 \pm 2.49 \mathrm{~A}$ \\
$M W D(\mathrm{~mm})$ & $0.82 \pm 0.08 \mathrm{~A}$ & $0.80 \pm 0.02 \mathrm{~A}$ & $0.66 \pm 0.04 \mathrm{~B}$ & $0.67 \pm 0.02 \mathrm{~B}$ \\
$G M D(\mathrm{~mm})$ & $0.51 \pm 0.03 \mathrm{~A}$ & $0.47 \pm 0.01 \mathrm{~B}$ & $0.42 \pm 0.02 \mathrm{C}$ & $0.43 \pm 0.02 \mathrm{C}$ \\
$F D$ & $2.14 \pm 0.06 \mathrm{C}$ & $2.19 \pm 0.07 \mathrm{~B}$ & $2.24 \pm 0.07 \mathrm{~A}$ & $2.23 \pm 0.07 \mathrm{~A}$ \\
$K$ & $0.06 \pm 0.01 \mathrm{C}$ & $0.07 \pm 0.02 \mathrm{~B}$ & $0.08 \pm 0.01 \mathrm{~A}$ & $0.08 \pm 0.02 \mathrm{~A}$ \\
\hline
\end{tabular}

Note: Values are means \pm SE $(n=3)$. The different capital letters indicate significant differences in the same aggregate size among different forest types $(p<0.05)$. MWD: mean weight diameter, GMD: geometric mean diameter, FD: fractal dimension, $K$ : soil erodibility factor.

Forest conversion significantly $(p<0.05)$ decreased $M W D$ and GMD values, indicating that aggregate stability declined. The MWD values for $\mathrm{CF}, \mathrm{AF}$, and $\mathrm{HF}$ decreased by $2.43 \%$, $20.51 \%$, and $18.29 \%$ respectively, compared with CBF (Table 3). The GMD followed a similar pattern to that of $M W D$. Among economic forests, the values of $M W D$ and GMD in CF $(0.80 \mathrm{~mm}, 0.47 \mathrm{~mm})$ were significantly higher than those in $\mathrm{AF}(0.66 \mathrm{~mm}, 0.43 \mathrm{~mm})$ and HF $(0.67 \mathrm{~mm}, 0.43 \mathrm{~mm})$ after forest conversion. The $F D$ and $K$ values for CBF were significantly lower than those of $\mathrm{CF}, \mathrm{AF}$, and HF. However, there were no significant differences between AF and HF. This indicates that long-term intensive management can reduce soil stability and aggravate the negative impacts caused by forest conversion, especially in forest types with severe erosion. 


\subsection{Aggregate-Associated SOC Contents}

$\mathrm{SOC}$ contents in the macro-aggregate fraction were significantly higher than those in the micro-aggregate fraction (Figure 2). The SOC contents in each aggregate fraction decreased significantly after conversion to economic forests, with the largest decreases occurring in AF. The decreases in macro-aggregate SOC content were greater than the decreases in micro-aggregate SOC. For example, the SOC content in $>1 \mathrm{~mm}$ aggregates decreased by $46.47 \%$ after conversion from $\mathrm{CBF}$ to $\mathrm{AF}$. This was a larger decrease than in CF $(33.51 \%)$ and HF (34.03\%). In addition, we also found that the SOC content of microaggregates among three economic forests appeared to follow the pattern: $\mathrm{CF}\left(14.97 \mathrm{~g} \mathrm{~kg}^{-1}\right)$ $>\mathrm{HF}\left(14.32 \mathrm{~g} \mathrm{~kg}^{-1}\right)>\operatorname{AF}\left(12.7 \mathrm{~g} \mathrm{~kg}^{-1}\right)$.

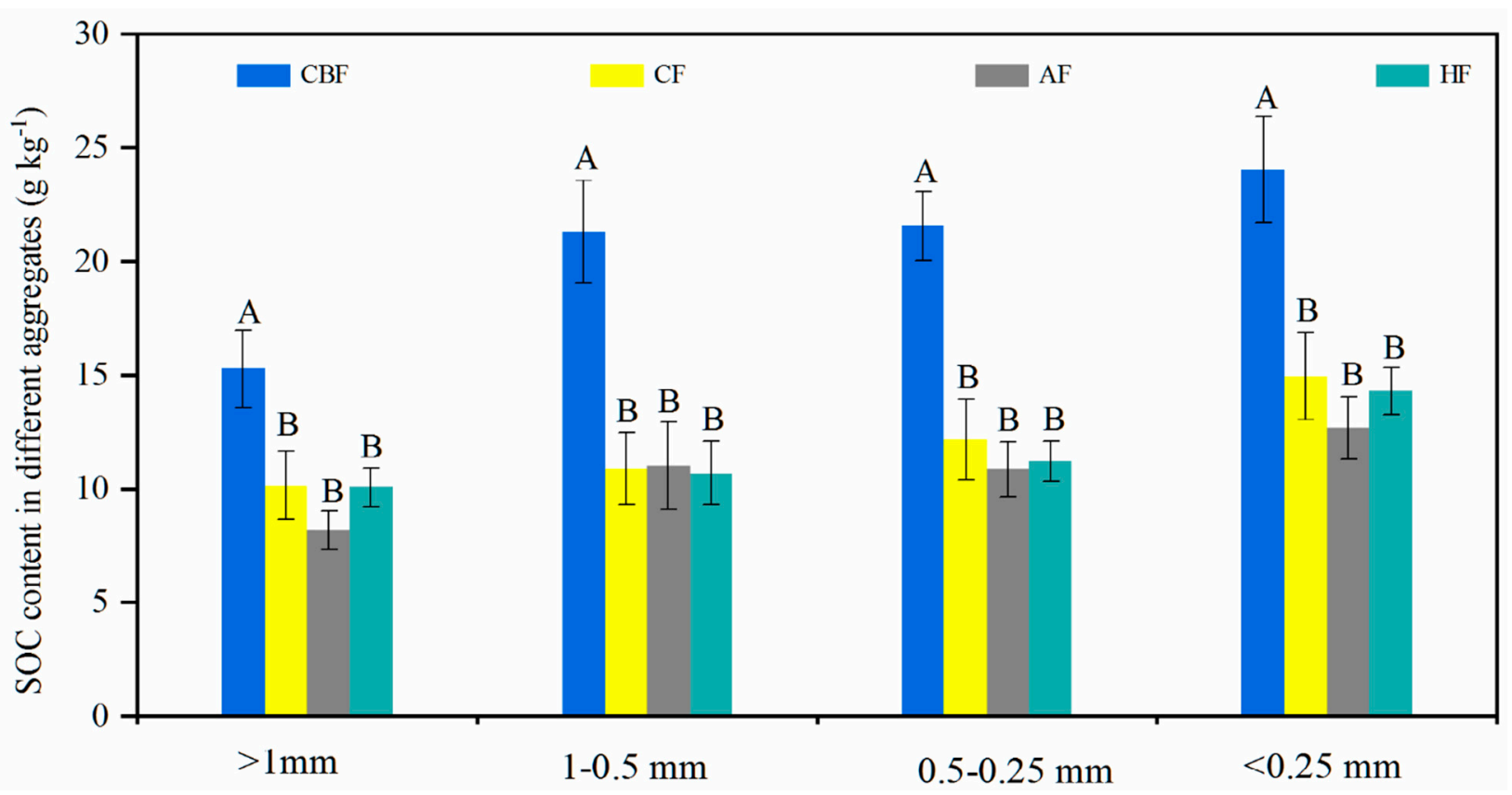

Figure 2. SOC for each aggregate fraction of the different forest types. Note: The different capital letters indicate significant differences in the same aggregate size among different forest types $(p<0.05)$. Values are means \pm standard errors.

The stepwise correlation analysis indicated that the ${ }^{137} \mathrm{C}_{\mathrm{S}}$ activity in the soil showed an extremely significant positive correlation with the aggregate-associated SOC content of water-stable aggregates less than $0.25,0.25-0.50$, and $0.5-1.0 \mathrm{~mm}\left(R^{2}=0.77,0.68\right.$, and 0.67 , $p<0.001$ ), and showed a significant positive correlation with the aggregate-associated SOC content of water-stable aggregate with greater than $1.0 \mathrm{~mm}\left(R^{2}=0.48, p<0.05\right)$ (Table 4$)$.

Table 4. Correlation between ${ }^{137} \mathrm{Cs}$ and organic carbon content of aggregates.

\begin{tabular}{|c|c|c|c|c|}
\hline Parameters & $>1 \mathrm{~mm}$ & $1-0.5 \mathrm{~mm}$ & $0.5-0.25 \mathrm{~mm}$ & $<0.25 \mathrm{~mm}$ \\
\hline${ }^{137} \mathrm{Cs}$ & $0.48 *$ & $0.67^{* *}$ & $0.68^{* *}$ & $0.77^{* *}$ \\
\hline$>1 \mathrm{~mm}$ & & $0.76^{* *}$ & $0.72 * *$ & $0.54^{* *}$ \\
\hline $1-0.5 \mathrm{~mm}$ & & & $0.84^{* *}$ & $0.69^{* *}$ \\
\hline $0.5-0.25 \mathrm{~mm}$ & & & & $0.81^{* *}$ \\
\hline$<0.25 \mathrm{~mm}$ & & & & 1 \\
\hline
\end{tabular}

\subsection{SOC Sequestration of Soil Aggregates}

The shift of forest type significantly reduced the SOC storage of soil aggregates (Figure 3). Compared with CBF $\left(82.23 \mathrm{Mg} \mathrm{hm}^{-2}\right)$, the storage of SOC in CF, AF, and HF were decreased by $41.4 \%, 47.96 \%$, and $43.78 \%$, respectively. Macro-aggregates represent the major pool of SOC in forest soil. As a form of SOC storage, macro-aggregates reveal the rising or falling trends of SOC pools. The SOC storage of macro-aggregates for CBF was 
$59.92 \mathrm{Mg} \mathrm{hm}^{-2}$, accounting for $68.94 \%$ of total SOC storage. Macro-aggregate-associated SOC stocks decreased significantly after conversion of CBF to economic forests. Compared with CBF, the SOC storage of macro-aggregates in CF, AF, and HF decreased by $44.57 \%$, $48.74 \%$, and $46.36 \%$, respectively. Meanwhile, we also found that the SOC storage of aggregates decreased with increasing particle size. However, we observed that the relatively large macro-aggregate SOC storage did not notably change between each forest type. This suggests that after the conversion of CBF into economic forests, the redistribution of SOC shifted from macro-aggregates $(>1 \mathrm{~mm})$ to micro-aggregates $(<0.25 \mathrm{~mm})$, with little effect on relatively large macro-aggregates $(0.25-1.0 \mathrm{~mm})$.

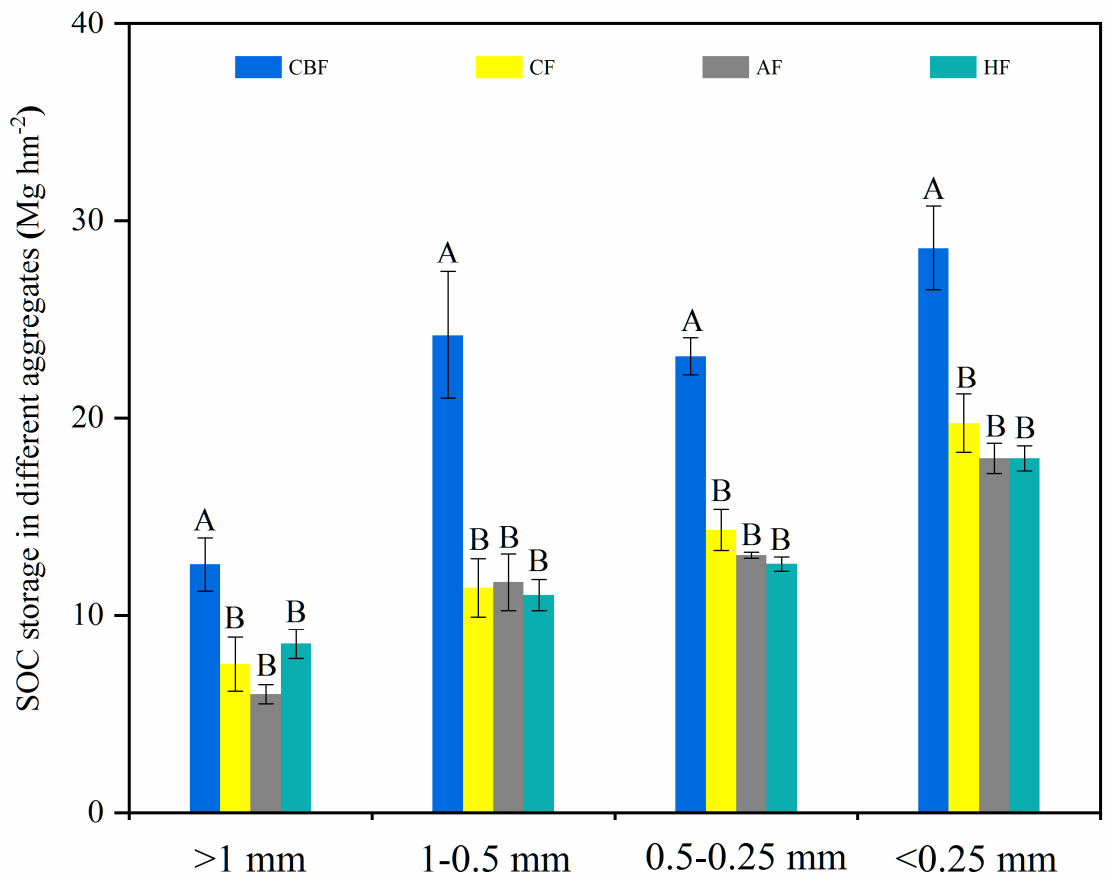

Figure 3. SOC storage for each aggregate fraction in the different forest types. Note: The different capital letters indicate significant differences in the same aggregate size among different forest types $(p<0.05)$. Values are expressed as means \pm standard errors.

As shown in Figure 4, the average annual loss of SOC in aggregates for CBF was $0.24 \mathrm{Mg} \mathrm{hm}^{-2}$. In economic forests, the aggregate-associated SOC loss in AF, HF, and CF was $1.57,1.30$, and 0.64 times that of CBF, respectively. Moreover, we observed that SOC is mainly stored in macro-aggregates and was subsequently lost, accounting for approximately $60 \%$ of the total loss. In economic forests, the lost SOC storage of macro-aggregates followed the pattern: CF $\left(0.09 \mathrm{Mg} \mathrm{hm}^{-2}\right)<\mathrm{HF}\left(0.19 \mathrm{Mg} \mathrm{hm}^{-2}\right)<\mathrm{AF}\left(0.24 \mathrm{Mg} \mathrm{hm}^{-2}\right)$. This suggests that CF are conducive to the accumulation of SOC and resistant to soil erosion when compared with the three types of economic forests. 


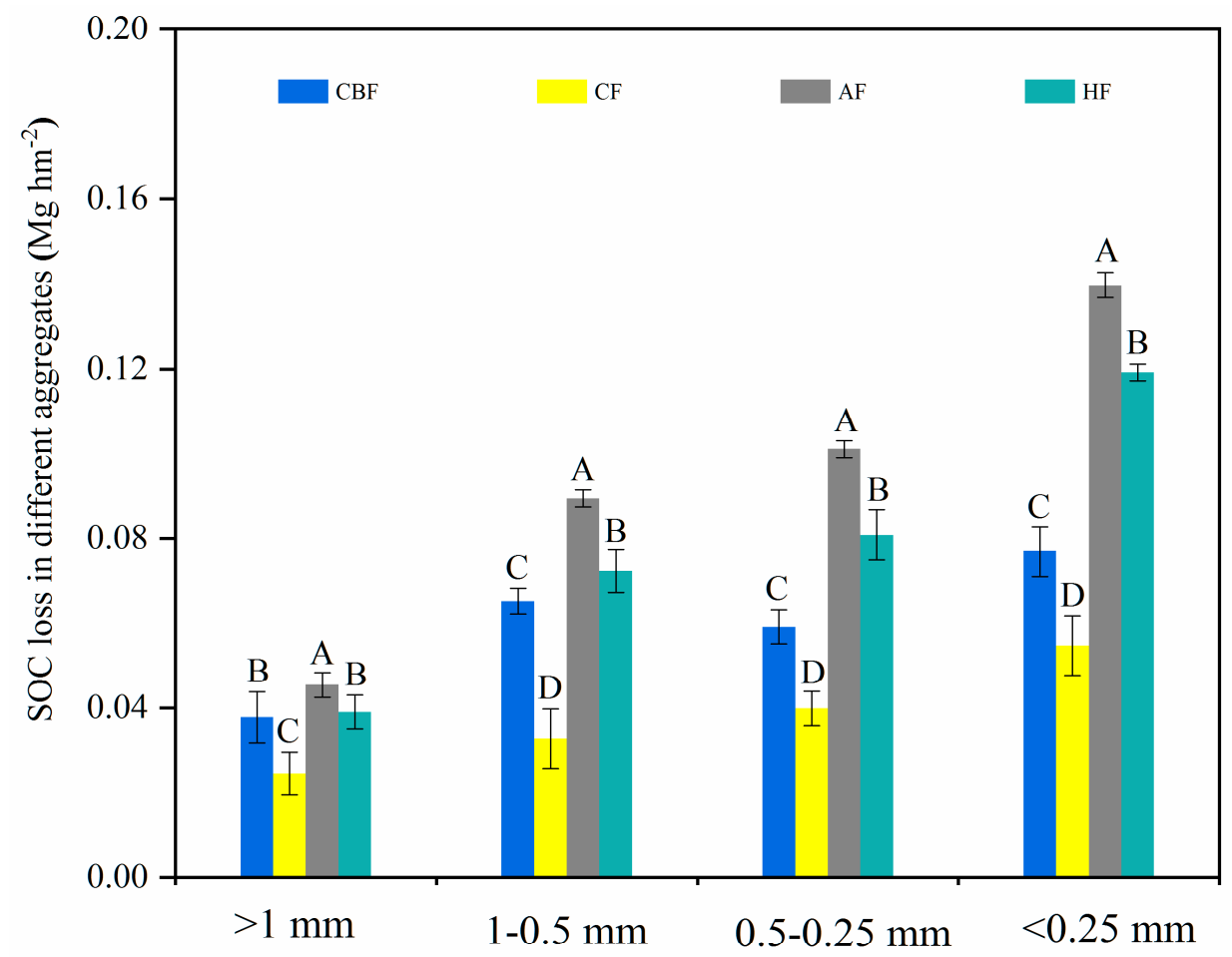

Figure 4. SOC loss for each aggregate fraction of the different forest types. Note: The different capital letters indicate significant differences in the same aggregate size among different forest types $(p<0.05)$. Values are means \pm standard errors.

\section{Discussion}

\subsection{Effect of Forest Conversion on the Distribution and Stability of Soil Aggregates}

Forest transformation will alter the soil microhabitat and affect soil physicochemical properties, which in turn contributes to the distribution of soil aggregates [6,53]. The proportion of aggregates not only has an impact on soil fertility, but is also the cornerstone of soil structural stability $[22,54]$. This study showed that when converting CBF into AF, HF, and $\mathrm{CF}$, the content of macro-aggregates was significantly higher in $\mathrm{CBF}(72.11 \%)$ than that in $\mathrm{CF}(70.42 \%), \mathrm{AF}(67.59 \%)$, and $\mathrm{HF}(68.14 \%)$, showing that forest management operations accelerate the breakdown of macro-aggregates. The values of MWD and GWD of AF, $\mathrm{HF}$, and $\mathrm{CF}$ significantly decreased, while the values of $F D$ and $K$ significantly increased, suggesting that the stability of aggregates declined following the forest conversion. The possible explanation would be that the structure of CBF was complex, with shrub, grass, and litter in the understory, and the root system was also more prosperous, which can effectively prevent the splashing of raindrops and the scouring of surface runoff, protecting the macroaggregates from being destroyed, thereby improving the stability of soil structure $[19,55,56]$. CF suffers little anthropogenic interference, and the humus layer is copious, which reduces the scouring force by rainfall, making it less vulnerable to water erosion and more resistant to external disturbances. On the other hand, the organic residues of CF could activate the microbial community during decomposition and lead to an increase in species of fungi and bacteria [57], while the root exudates and enzymes produced by those fungi and bacteria could provide a material basis for the formation of macro-aggregates, thereby augmenting the stability of soil aggregates and improving soil quality [9,57-59]. Conversely, in order to prevent the occurrence of insects and diseases, tillage treatment and removal of understory vegetation were annually performed in $\mathrm{AF}$, and the litter of $\mathrm{HF}$ was removed. These management practices greatly increase anthropogenic disruption, which accelerates the destruction of macro-aggregates and increases soil aeration, resulting in a poorer protection of soil particles, looser soil structure, lower content of SOM, and a decrease in the abundance of fungi and bacteria [60-62]. AF and HF were also subjected to a greater 
destruction degree under the same external force conditions, and thus their stability of soil aggregates was less stable. Overall, management measures such as minimizing the surface disturbance and increasing the ground coverage should be implemented in economic forest construction to improve the SOM content and microbial populations, which enhance the stability of soil aggregates and improve soil structure $[52,63]$.

\subsection{Effect of Forest Conversion on Aggregate-Associated SOC Storage}

Soil aggregation has a significant effect on the stability of SOC, and it promotes a suitable microbial environment for the physical protection of soil and absorption of particulate organic matter $[54,64]$. The soil physicochemical properties, such as the clay content, water content, and temperature, will also change following the forest conversion, and these changes will in turn impact the SOC mineralization and accumulation [30,65]. In this study, compared with $\mathrm{CF}$, the soil erosion modulus was significantly higher in $\mathrm{AF}$ and HF after intensive management (Table 1), and the content of clay particles, SOC in macro-aggregates, and $\mathrm{C} / \mathrm{N}$ ratio were lower in $\mathrm{AF}$ and $\mathrm{HF}$, indicating enhanced SOC mineralization and reduced cementing substances. This is because macro-aggregates will break down by intensive management, and soil organic matter was exposed, making it easier to be mineralized and decomposed by microorganisms [66-69]. Conversely, SOC in micro-aggregates is generally difficult to decompose [62]. Accordingly, in contrast to CF, $\mathrm{SOC}$ in $\mathrm{AF}$ and $\mathrm{HF}$ is more concentrated in micro-aggregates. This is consistent with the findings of Six et al. [70], who found that tillage practices and their intensity significantly influence the accumulation of soil organic matter, and intensive management will accelerate its transformation and reduce the formation of aggregation.

The soil erosion modulus was significantly higher after conversion from CBF to these three economic frosts and remarkably differed between stand types (Table 1). AF is susceptible to the most severe soil erosion, followed by HF, while soil erosion and water loss would be relatively mild in CF. After forest transformation, aggregate-associated SOC stocks differed in the order of $\mathrm{CF}>\mathrm{HF}>\mathrm{AF}$, which was exactly the opposite of the soil erosion modulus (Table 1, Figure 2). These results were also consistent with the results of Chen et al. [71], who found that converting from CBF to economic forests reduced the SOC storage related to aggregates. Previous literature reported that forest-type shifts and their subsequent intensive management will increase soil erosion, disrupt the stability of aggregates, and increase soil $\mathrm{C}$ loss. Although the rainfall and topography of $\mathrm{CBF}, \mathrm{AF}$, $\mathrm{HF}$, and CF were similar, the aggregate-associated SOC stock of CBF was significantly higher than the three economic forests. This can be attributed to the increase in SOM export from economic forests and the increase in erosion intensity that takes away more SOC. Although the SOC content was increased through human input to a certain extent, the soil structure was destroyed, leading to the decline of soil aggregate stability [72]. Additionally, the content of SOC was the least in $\mathrm{AF}$, with strong anthropogenic disturbance and bare surface, mainly due to the difference in depletion of forest growth, soil erosion, and some human disturbances. For example, the understory condition of $\mathrm{CF}$ was superior, and its humus-rich surface featured a high organic matter content, which had a supplementary effect on SOC via microbial decomposition, and undoubtedly, the SOC loss induced by erosion was smaller than AF and HF. Accordingly, the content of aggregated-associated SOC in CF was higher than that of AF and HF.

However, the responses of different economic forest species to intensive management were different. Both HF and AF were intensively managed, but the soil erosion modulus and the amount of aggregate-associated SOC lost from AF were higher than in HF (Table 1 and Figure 4), which was mainly related to different tree species [8]. Several studies [73-75] have confirmed that apple trees are deep-rooted plants that require higher moisture, and this demand increases with stand age, which could partly explain why the SOC storage in AF was lowest. Furthermore, in this study, rainfall is abundant in this region, but there is insufficient soil water storage and high evaporation due to the high content of sand particles and the shallow soil layer [38]. Apple trees grow roots that can obtain deeper 
levels of moisture, which can have a drying effect on the surrounding soil [75]. When rainfall occurs, soil dryness exacerbates soil erosion induced by intensive management, which was in line with our findings. Consequently, $\mathrm{CF}^{\prime}$ s pattern was the optimum choice compared to AF and HF in the process of developing economic forests. Meanwhile, some measures, such as planting tea, grass, or medicine in the understory, fungicide application, less-tillage, and no-tillage to increase the ground cover $[55,57,66]$, can be taken to control soil erosion and enhance the SOC content and its stability, thereby promoting the formation of soil macro-aggregates.

\subsection{Estimation of SOC Loss Using ${ }^{137} C_{S}$}

The results of correlation analysis demonstrated that ${ }^{137} \mathrm{C}_{\mathrm{S}}$ and SOC related to aggregates were significantly positively correlated, indicating that ${ }^{137} \mathrm{C}_{\mathrm{S}}$ and aggregateassociated SOC have similar patterns in the context of soil erosion, which is consistent with the previous study [4]. It was observed that SOC varies with the migration of soil particles, and thus ${ }^{137} \mathrm{C}_{\mathrm{S}}$ and SOC have similar patterns in the process of erosion and deposition. This was mainly attributed to the fragmentation of macro-aggregates by soil erosion, especially water erosion, resulting in the migration of carbon along with fine particles, thereby causing the loss of SOC from in-situ soils [65]. Thus, under the changes in land-use, differences in the process of separation, translocation, and deposition of erosion will lead to differences in $C$ transport [76].

In addition, the SOC loss in surface soil aggregates decreased by $0.15,0.38$, and $0.31 \mathrm{Mg} \mathrm{hm}^{-2}$ following the conversion from CBF to CF, AF, and HF respectively (Figure 3), implying that $\mathrm{CF}$ mode is more conducive to SOC accumulation. It is estimated that the conversion to intensively managed economic forests would result in a decrease of $6.47 \times 106 \mathrm{~kg}$ of SOC in the soil surface layer of the Huaibei Rocky Mountain Areas, which would cause losses of soil and water resources and nutrients [69]. The decrease in aggregateassociated SOC stock demonstrated that the stable structure of soil is destroyed, which led to land degradation, water eutrophication, and a decrease in soil productivity of economic forests, in turn jeopardizing the development of local agroforestry [77-79]. Therefore, soil erosion caused by forest conversion and intensive management cannot be ignored when exploring the effect of soil erosion on aggregate-associated SOC using ${ }^{137} \mathrm{Cs}$.

\section{Conclusions}

Conversion of $\mathrm{CBF}$ to three economic forests and subsequent intensive management reduced aggregate stability, accelerated aggregate fragmentation, and decreased the proportion of macro-aggregates, which in turn produced decreases in the storage of SOC in aggregates. Macro-aggregates are the main storage forms of SOC in aggregates, and the decrease in macro-aggregates adequately explains the loss of SOC in aggregate fractions. Among economic forests, $\mathrm{CF}$ exhibits higher aggregate stability and SOC storage compared to $\mathrm{HF}$ and AF. This is mainly due to better vegetation cover and low human disturbance. Intensive management in $\mathrm{AF}$ and $\mathrm{CF}$ has led to the intensification of soil erosion and accelerated the loss of soil aggregates, which is not conducive to the accumulation of SOC. According to the results of the quantitative relationship calculation, the SOC losses in the aggregates of $\mathrm{CF}, \mathrm{AF}$, and $\mathrm{HF}$ were $0.15,0.38$, and $0.31 \mathrm{Mg} \mathrm{hm}^{-2}$, respectively. In the study area, soil erosion induced the loss of approximately $6.47 \times 10^{6} \mathrm{~kg}$ of aggregate-associated SOC, on average, due to intensive management in AF and HF. These results will provide support for monitoring land degradation and preventing soil erosion in the area. Overall, our research indicates that soil erosion induced by forest management operations has a negative impact on soil structure and nutrient storage. Therefore, when developing economic forests in the Huaibei Rocky Mountain Area, we should choose appropriate tree species and adopt proper forest management practices, such as growing tea or medicinal plants to increase surface cover, to reduce soil erosion and achieve sustainable development of economic forests. In addition, seeking a balance between economic benefits and the ecological environment should be an urgent topic for future research. 
Author Contributions: Conceptualization, writing-original draft, review and editing, G.G. and X.L.; methodology and data curation, Y.X.; formal analysis and software, Q.D.; investigation, X.Z. and G.Z.; visualization, G.G.; project administration, J.L. and X.L.; funding acquisition and supervision, J.L. All authors have read and agreed to the published version of the manuscript.

Funding: This study was funded by the National Natural Science Foundation of China (31870600), Nation Key R\&D Program of China (2017YFC0505505), and Priority Academic Program Development of Jiangsu Higher Education Institutions (PAPD).

Data Availability Statement: Data sharing is not applicable to this article.

Acknowledgments: We would like to thank all the colleagues who participated in this research in one way or another during the experiments but were not included in the final authors' list.

Conflicts of Interest: The authors declare no conflict of interest.

\section{References}

1. Deng, L.; Kim, D.-G.; Li, M.; Huang, C.; Liu, Q.; Cheng, M.; Shangguan, Z.; Peng, C. Land-use changes driven by 'Grain for Green' program reduced carbon loss induced by soil erosion on the Loess Plateau of China. Glob. Planet. Chang. 2019, 177, 101-115. [CrossRef]

2. Li, Q.; Yu, P.; Li, G.; Zhou, D.; Chen, X. Overlooking soil erosion induces underestimation of the soil C loss in degraded land. Quat. Int. 2014, 349, 287-290. [CrossRef]

3. Wang, Y.; Ran, L.; Fang, N.; Shi, Z. Aggregate stability and associated organic carbon and nitrogen as affected by soil erosion and vegetation rehabilitation on the Loess Plateau. Catena 2018, 167, 257-265. [CrossRef]

4. LiuSui, Y.; Zhu, X.; Li, D.; Yan, C.; Sun, T.; Jia, H.; Zhao, X. Soil aggregate and intra-aggregate carbon fractions associated with vegetation succession in an alpine wetland of Northwest China. Catena 2019, 181, 104107. [CrossRef]

5. Six, J.; Callewaert, P.; Lenders, S.; De Gryze, S.; Morris, S.J.; Gregorich, E.G.; Paul, E.A.; Paustian, K. Measuring and Understanding Carbon Storage in Afforested Soils by Physical Fractionation. Soil Sci. Soc. Am. J. 2002, 66, 1981-1987. [CrossRef]

6. Six, J.; Bossuyt, H.; Degryze, S.; Denef, K. A history of research on the link between (micro)aggregates, soil biota, and soil organic matter dynamics. Soil Tillage Res. 2004, 79, 7-31. [CrossRef]

7. Ghosh, B.; Meena, V.; Alam, N.; Dogra, P.; Bhattacharyya, R.; Sharma, N.; Mishra, P. Impact of conservation practices on soil aggregation and the carbon management index after seven years of maize-wheat cropping system in the Indian Himalayas. Agric. Ecosyst. Environ. 2016, 216, 247-257. [CrossRef]

8. Wang, H.; Jin, J.; Yu, P.; Fu, W.; Morrison, L.; Lin, H.; Meng, M.; Zhou, X.; Lv, Y.; Wu, J. Converting evergreen broad-leaved forests into tea and Moso bamboo plantations affects labile carbon pools and the chemical composition of soil organic carbon. Sci. Total. Environ. 2020, 711, 135225. [CrossRef] [PubMed]

9. Wu, W.; Lin, H.; Fu, W.; Penttinen, P.; Li, Y.; Jin, J.; Zhao, K.; Wu, J. Soil organic carbon content and microbial functional diversity were lower in monospecific chinese hickory stands than in natural chinese hickory-broad-leaved mixed forests. Forests 2019, 10, 357. [CrossRef]

10. Pan, Y.; Birdsey, R.A.; Fang, J.; Houghton, R.; Kauppi, P.E.; Kurz, W.A.; Phillips, O.; Shvidenko, A.; Lewis, S.L.; Canadell, J.; et al. A large and persistent carbon sink in the World's forests. Science 2011, 333, 988-993. [CrossRef]

11. Li, Y.; Zhang, J.; Chang, S.; Jiang, P.; Zhou, G.; Shen, Z.; Wu, J.; Lin, L.; Wang, Z.; Shen, M. Converting native shrub forests to Chinese chestnut plantations and subsequent intensive management affected soil C and N pools. For. Ecol. Manag. 2014, 312, 161-169. [CrossRef]

12. Liu, Y.; Liu, W.; Wu, L.; Liu, C.; Wang, L.; Chen, F.; Li, Z. Soil aggregate-associated organic carbon dynamics subjected to different types of land use: Evidence from 13C natural abundance. Ecol. Eng. 2018, 122, 295-302. [CrossRef]

13. Li, Z.; Zhang, G.-H.; Geng, R.; Wang, H.; Zhang, X. Land use impacts on soil detachment capacity by overland flow in the Loess Plateau, China. Catena 2015, 124, 9-17. [CrossRef]

14. Wang, Y.; Zhang, J. Influences of intensive tillage on water-stable aggregate distribution on a steep hillslope. Soil Tillage Res. 2015, 151, 82-92. [CrossRef]

15. Weidhuner, A.; Hanauer, A.; Krausz, R.; Crittenden, S.J.; Gage, K.; Sadeghpour, A. Tillage impacts on soil aggregation and aggregate-associated carbon and nitrogen after 49 years. Soil Tillage Res. 2021, 208, 104878. [CrossRef]

16. Okolo, C.C.; Gebresamuel, G.; Zenebe, A.; Haile, M.; Eze, P.N. Accumulation of organic carbon in various soil aggregate sizes under different land use systems in a semi-arid environment. Agric. Ecosyst. Environ. 2020, 297, 106924. [CrossRef]

17. Zhong, Z.; Han, X.; Xu, Y.; Zhang, W.; Fu, S.; Liu, W.; Ren, C.; Yang, G.; Ren, G. Effects of land use change on organic carbon dynamics associated with soil aggregate fractions on the Loess Plateau, China. Land Degrad. Dev. 2019, 30, 1070-1082. [CrossRef]

18. Saha, D.; Kukal, S.S.; Sharma, S. Landuse impacts on SOC fractions and aggregate stability in typic ustochrepts of Northwest India. Plant Soil 2011, 339, 457-470. [CrossRef]

19. An, J.; Liu, Q. Soil aggregate breakdown in response to wetting rate during the inter-rill and rill stages of erosion in a contour ridge system. Catena 2017, 157, 241-249. [CrossRef]

20. Lal, R. Soil erosion and carbon dynamics. Soil Tillage Res. 2005, 81, 137-142. [CrossRef] 
21. Liu, S.; Dong, Y.; Cheng, F.; Yin, Y.; Zhang, Y. Variation of soil organic carbon and land use in a dry valley in Sichuan province, Southwestern China. Ecol. Eng. 2016, 95, 501-504. [CrossRef]

22. Vermang, J.; Demeyer, V.; Cornelis, W.; Gabriels, D. Aggregate stability and erosion response to antecedent water content of a loess soil. Soil Sci. Soc. Am. J. 2009, 73, 718-726. [CrossRef]

23. Zhang, H.; Wang, K.; Zeng, Z.; Du, H.; Zou, Z.; Xu, Y.; Zeng, F. Large-scale patterns in forest growth rates are mainly driven by climatic variables and stand characteristics. For. Ecol. Manag. 2019, 435, 120-127. [CrossRef]

24. Vesterdal, L.; Ritter, E.; Gundersen, P. Change in soil organic carbon following afforestation of former arable land. For. Ecol. Manag. 2002, 169, 137-147. [CrossRef]

25. Zhao, Y.; Li, M.; Deng, J.; Wang, B. Afforestation affects soil seed banks by altering soil properties and understory plants on the eastern Loess Plateau, China. Ecol. Indic. 2021, 126, 107670. [CrossRef]

26. Burton, J.; Chen, C.; Xu, Z.; Ghadiri, H. Soluble organic nitrogen pools in adjacent native and plantation forests of subtropical Australia. Soil Biol. Biochem. 2007, 39, 2723-2734. [CrossRef]

27. Eclesia, R.P.; Jobbagy, E.G.; Jackson, R.B.; Biganzoli, F.; Piñeiro, G. Shifts in soil organic carbon for plantation and pasture establishment in native forests and grasslands of South America. Glob. Chang. Biol. 2012, 18, 3237-3251. [CrossRef]

28. Li, G.-L.; Pang, X.-M. Effect of land-use conversion on C and $\mathrm{N}$ distribution in aggregate fractions of soils in the southern Loess Plateau, China. Land Use Policy 2010, 27, 706-712. [CrossRef]

29. Laiho, R.; Sanchez, F.; Tiarks, A.; Dougherty, P.M.; Trettin, C.C. Impacts of intensive forestry on early rotation trends in site carbon pools in the southeastern US. For. Ecol. Manag. 2003, 174, 177-189. [CrossRef]

30. Meng, M.; Lin, J.; Guo, X.; Liu, X.; Wu, J.; Zhao, Y.; Zhang, J. Impacts of forest conversion on soil bacterial community composition and diversity in subtropical forests. Catena 2019, 175, 167-173. [CrossRef]

31. Wu, J.-S.; Jiang, P.-K.; Chang, S.; Xu, Q.-F.; Lin, Y. Dissolved soil organic carbon and nitrogen were affected by conversion of native forests to plantations in subtropical China. Can. J. Soil Sci. 2010, 90, 27-36. [CrossRef]

32. Fang, X.; Zhang, J.; Meng, M.; Guo, X.; Wu, Y.; Liu, X.; Zhao, K.; Ding, L.; Shao, Y.; Fu, W. Forest-type shift and subsequent intensive management affected soil organic carbon and microbial community in southeastern China. Eur. J. For. Res. 2017, 136, 689-697. [CrossRef]

33. Guo, X.; Chen, H.; Meng, M.; Biswas, S.; Ye, L.; Zhang, J. Effects of land use change on the composition of soil microbial communities in a managed subtropical forest. For. Ecol. Manag. 2016, 373, 93-99. [CrossRef]

34. Zhu, G.; Deng, L.; Shangguan, Z. Effects of soil aggregate stability on soil $\mathrm{N}$ following land use changes under erodible environment. Agric. Ecosyst. Environ. 2018, 262, 18-28. [CrossRef]

35. Shu, X.; Zhu, A.-N.; Zhang, J.-B.; Yang, W.-L.; Xin, X.-L.; Zhang, X.-F. Changes in soil organic carbon and aggregate stability after conversion to conservation tillage for seven years in the Huang-Huai-Hai Plain of China. J. Integr. Agric. 2015, 14, 1202-1211. [CrossRef]

36. Zhao, J.; Chen, S.; Hu, R.; Li, Y. Aggregate stability and size distribution of red soils under different land uses integrally regulated by soil organic matter, and iron and aluminum oxides. Soil Tillage Res. 2017, 167, 73-79. [CrossRef]

37. Zhao, F.; Fan, X.; Ren, C.; Zhang, L.; Han, X.; Yang, G.; Wang, J.; Doughty, R. Changes of the organic carbon content and stability of soil aggregates affected by soil bacterial community after afforestation. Catena 2018, 171, 622-631. [CrossRef]

38. Zhu, X.; Lin, J.; Dai, Q.; Xu, Y.; Li, H. Evaluation of Forest Conversion Effects on Soil Erosion, Soil Organic Carbon and Total Nitrogen Based on Cs-137 Tracer Technique. Forests 2019, 10, 433. [CrossRef]

39. Berhe, A.A.; Harte, J.; Harden, J.W.; Torn, M. The significance of the erosion-induced terrestrial carbon sink. Bioscience 2007, 57, 337-346. [CrossRef]

40. Nie, X.; Li, Z.; Huang, J.; Liu, L.; Xiao, H.; Liu, C.; Zeng, G. Thermal stability of organic carbon in soil aggregates as affected by soil erosion and deposition. Soil Tillage Res. 2018, 175, 82-90. [CrossRef]

41. Walling, D.E.; He, Q.; Blake, W. Use of 7Be and 137Cs measurements to document short- and medium-term rates of water-induced soil erosion on agricultural land. Water Resour. Res. 1999, 35, 3865-3874. [CrossRef]

42. Yang, Y.-H.; Yan, B.-X.; Zhu, H. Estimating soil erosion in Northeast China using 137Cs and 210Pbex. Pedosphere 2011, $21,706-711$. [CrossRef]

43. Koarashi, J.; Nishimura, S.; Atarashi-Andoh, M.; Matsunaga, T.; Sato, T.; Nagao, S. Radiocesium distribution in aggregate-size fractions of cropland and forest soils affected by the Fukushima nuclear accident. Chemosphere 2018, 205, 147-155. [CrossRef]

44. Wrb, I. World Reference Base for Soil Resources, 2nd ed.; FAO: Rome, Italy, 2006.

45. Zhao, W.; Fierro, V.; Fernández-Huerta, N.; Izquierdo, M.T.; Celzard, A. Hydrogen uptake of high surface area-activated carbons doped with nitrogen. Int. J. Hydrogen Energy 2013, 38, 10453-10460. [CrossRef]

46. Page, A.L.; Miller, R.H.; Keeney, D.R. Chemical and microbiological properties. In Methods of Soil Analysis; American Society of Agronomy Inc \& Soil Science Society of America Inc.: Madison, WI, USA, 1982.

47. Jones, D.L.; Willett, V.B. Experimental evaluation of methods to quantify dissolved organic nitrogen (DON) and dissolved organic carbon (DOC) in soil. Soil Biol. Biochem. 2006, 38, 991-999. [CrossRef]

48. ISSAS. Soil Physical and Chemical Analysis; Shanghai Science and Technology Press: Shanghai, China, 1978; pp. 515-517.

49. Bavel, C. Mean weight-diameter of soil aggregates as a statistical index of aggregation. Soil Sci. Soc. Am. J. 1950, 14, 20-23. [CrossRef] 
50. Gardner, W.R. Representation of soil aggregate-size distribution by a logarithmic-normal distribution. Soil Sci. Soc. Am. J. 1956, 20, 151-153. [CrossRef]

51. Qi, F.; Zhang, R.; Liu, X.; Niu, Y.; Zhang, H.; Li, H.; Li, J.; Wang, B.; Zhang, G. Soil particle size distribution characteristics of different land-use types in the Funiu mountainous region. Soil Tillage Res. 2018, 184, 45-51. [CrossRef]

52. Ellert, B.H.; Bettany, J.R. Calculation of organic matter and nutrients stored in soils under contrasting management regimes. Can. J. Soil Sci. 1995, 75, 529-538. [CrossRef]

53. Lyu, M.; Xie, J.; Ukonmaanaho, L.; Jiang, M.; Li, Y.; Chen, Y.; Yang, Z.; Zhou, Y.; Lin, W.; Yang, Y. Land use change exerts a strong impact on deep soil C stabilization in subtropical forests. J. Soils Sediments 2016, 17, 2305-2317. [CrossRef]

54. Mataix-Solera, J.; Cerdà, A.; Arcenegui, V.; Jordán, A.; Zavala, L.M.M. Fire effects on soil aggregation: A review. Earth Sci. Rev. 2011, 109, 44-60. [CrossRef]

55. Six, J.; Elliott, E.T.; Paustian, K. Soil macroaggregate turnover and microaggregate formation: A mechanism for C sequestration under no-tillage agriculture. Soil Biol. Biochem. 2000, 32, 2099-2103. [CrossRef]

56. Shahzad, T.; Rashid, M.I.; Maire, V.; Barot, S.; Perveen, N.; Alvarez, G.; Fontaine, S. Root penetration in deep soil layers stimulates mineralization of millennia-old organic carbon. Soil Biol. Biochem. 2018, 124, 150-160. [CrossRef]

57. Bearden, B.N.; Petersen, L. Influence of arbuscular mycorrhizal fungi on soil structure and aggregate stability of a vertisol. Plant Soil 2000, 218, 173-183. [CrossRef]

58. De Moraes Sá, J.C.; Gonçalves, D.R.P.; Ferreira, L.A.; Mishra, U.; Inagaki, T.M.; Furlan, F.J.F.; de Oliveira Ferreira, A. Soil carbon fractions and biological activity based indices can be used to study the impact of land management and ecological successions. Ecol. Indic. 2018, 84, 96-105. [CrossRef]

59. Wu, Z.; Haack, S.E.; Lin, W.; Li, B.; Wu, L.; Fang, C.; Zhang, Z. Soil microbial community structure and metabolic activity of pinus elliottii plantations across different stand ages in a Subtropical Area. PLoS ONE 2015, 10, e0135354. [CrossRef]

60. Hui, Z.; Zhou, Y.; Ren, Q. Evolution of the soil bacterial community structure during the development of pinus massoniana plantations in subtropical china. Int. J. Agric. Biol. 2019, 22, 73-82.

61. Puget, P.; Chenu, C.; Balesdent, J. Dynamics of soil organic matter associated with particle-size fractions of water-stable aggregates. Eur. J. Soil Sci. 2010, 51, 595-605. [CrossRef]

62. Elliott, E.T. Aggregate structure and carbon, nitrogen, and phosphorus in native and cultivated soils. Soil Sci. Soc. Am. J. 1986, 50, 627. [CrossRef]

63. Merilä, P.; Malmivaara-Lämsä, M.; Spetz, P.; Stark, S.; Vierikko, K.; Derome, J.; Fritze, H. Soil organic matter quality as a link between microbial community structure and vegetation composition along a successional gradient in a boreal forest. Appl. Soil Ecol. 2010, 46, 259-267. [CrossRef]

64. Wang, Y.; Fu, B.; Lü, Y.; Chen, L. Effects of vegetation restoration on soil organic carbon sequestration at multiple scales in semi-arid Loess Plateau, China. Catena 2011, 85, 58-66. [CrossRef]

65. Yao, Y.; Liu, J.; Wang, Z.; Wei, X.; Zhu, H.; Fu, W.; Shao, M. Responses of soil aggregate stability, erodibility and nutrient enrichment to simulated extreme heavy rainfall. Sci. Total Environ. 2019, 709, 136150. [CrossRef]

66. Jiang, X.; Wright, A.L.; Wang, X.; Liang, F. Tillage-induced changes in fungal and bacterial biomass associated with soil aggregates: A long-term field study in a subtropical rice soil in China. Appl. Soil Ecol. 2011, 48, 168-173. [CrossRef]

67. Tisdall, J.M.; Oades, J.M. Organic matter and water-stable aggregates in soils. Eur. J. Soil Sci. 1982, 33, 141-163. [CrossRef]

68. An, S.; Mentler, A.; Mayer, H.; Blum, W.E. Soil aggregation, aggregate stability, organic carbon and nitrogen in different soil aggregate fractions under forest and shrub vegetation on the Loess Plateau, China. Catena 2010, 81, 226-233. [CrossRef]

69. $\mathrm{Hu}, \mathrm{Y}$.; Kuhn, N.J. Erosion-induced exposure of SOC to mineralization in aggregated sediment. Catena 2016, 137, 517-525. [CrossRef]

70. Six, J.; Elliott, E.; Paustian, K.; Doran, J.W. Aggregation and soil organic matter accumulation in cultivated and native grassland soils. Soil Sci. Soc. Am. J. 1998, 62, 1367-1377. [CrossRef]

71. Chen, G.-S.; Yang, Z.-J.; Gao, R.; Xie, J.-S.; Guo, J.-F.; Huang, Z.-Q.; Yang, Y.-S. Carbon storage in a chronosequence of Chinese fir plantations in southern China. For. Ecol. Manag. 2013, 300, 68-76. [CrossRef]

72. Zhang, Z.-S.; Song, X.-L.; Lu, X.-G.; Xue, Z. Ecological stoichiometry of carbon, nitrogen, and phosphorus in estuarine wetland soils: Influences of vegetation coverage, plant communities, geomorphology, and seawalls. J. Soils Sediments 2013, 13, $1043-1051$. [CrossRef]

73. Paul, S.; Flessa, H.; Veldkamp, E.; López-Ulloa, M. Stabilization of recent soil carbon in the humid tropics following land use changes: Evidence from aggregate fractionation and stable isotope analyses. Biogeochemistry 2008, 87, 247-263. [CrossRef]

74. Bateman, I.J.; Mace, G.; Fezzi, C.; Atkinson, G.; Turner, K. Economic analysis for ecosystem service assessments. Environ. Resour. Econ. 2010, 48, 177-218. [CrossRef]

75. Liu, Z.; Ma, P.; Zhai, B.; Zhou, J. Soil moisture decline and residual nitrate accumulation after converting cropland to apple orchard in a semiarid region: Evidence from the Loess Plateau. Catena 2019, 181, 104080. [CrossRef]

76. Yang, Y.; Guo, J.; Chen, G.; Yin, Y.; Gao, R.; Lin, C. Effects of forest conversion on soil labile organic carbon fractions and aggregate stability in subtropical China. Plant Soil 2009, 323, 153-162. [CrossRef]

77. Fernández-Raga, M.; Palencia, C.; Keesstra, S.; Jordán, A.; Fraile, R.; Angulo-Martinez, M.; Cerdà, A. Splash erosion: A review with unanswered questions. Earth Sci. Rev. 2017, 171, 463-477. [CrossRef] 
78. Lal, R. Accelerated soil erosion as a source of atmospheric $\mathrm{CO}_{2}$. Soil Tillage Res. 2019, 188, 35-40. [CrossRef]

79. Berhe, A.A.; Barnes, R.T.; Six, J.; Marín-Spiotta, E. Role of soil erosion in biogeochemical cycling of essential elements: Carbon, nitrogen, and phosphorus. Annu. Rev. Earth Planet. Sci. 2018, 46, 521-548. [CrossRef] 